\title{
High natural killer cell number might identify stroke patients at risk of developing infections
}

\section{OPEN}

Sylvie De Raedt, MD

Aurelie De Vos, MD

Anne-Marie Van Binst, MD

Marc De Waele, MD, $\mathrm{PhD}$

Danny Coomans, MD, $\mathrm{PhD}$

Ronald Buyl, $\mathrm{MD}, \mathrm{PhD}$ Jacques De Keyser, MD, $\mathrm{PhD}$

Correspondence to

Dr. De Raedt:

sylvie.deraedt@uzbrussel.be

\section{ABSTRACT}

Objective: To investigate early changes in leukocyte subsets and autonomic function as predictors of the development of poststroke infections.

Methods: We assessed the time course of leukocyte subsets in the blood of 59 patients with acute ischemic stroke. We divided the patients into 2 groups: those who developed infections during the first 7 days after stroke onset and those who did not. We measured urinary norepinephrine and epinephrine concentrations and pulse rate variability indices within 24 hours of admission.

Results: We found that the number of circulating natural killer (NK) cells within the first hours after stroke was higher in stroke patients who developed infections (mean 435 cells $/ \mathrm{mL} ; 95 \%$ confidence interval [Cl] 321-588) than in stroke patients who did not develop infections (mean 236 cells $/ \mathrm{mL} ; 95 \% \mathrm{Cl} 186-300 ; p=0.001$ ). This was followed by a decrease in all lymphocyte subsets from admission to day 1, varying between $22 \%$ and $40 \%$, which was not seen in patients without poststroke infection (mean increase varied between $2 \%$ and $23 \%$; all $p<$ 0.005). In the group that developed infections, pulse rate variability revealed a decreased high frequency component. These findings all remained significant after adjustment for age and stroke volume.

Conclusions: High circulating NK cell count within the first hours after ischemic stroke onset followed by a drop in all lymphocyte subsets identified patients who developed infections and may be caused by a sympathovagal imbalance with sympathetic overweight. These findings need to be validated in larger studies. Neurol Neuroimmunol Neuroinflamm 2015;2:e71; doi: 10.1212/ NXI.0000000000000071

\section{GLOSSARY}

ANCOVA = analysis of covariance; $\mathbf{C R P}=$ C-reactive protein; $\mathbf{D W I}=$ diffusion-weighted imaging; $\mathbf{H F}=$ high frequency range; $\mathbf{H R V}=$ heart rate variability; $\mathbf{I Q R}=$ interquartile range; $\mathbf{L F}=$ low frequency range; $\mathbf{N K}=$ natural killer; $\mathbf{N K T}=$ natural killer $\mathrm{T}$ cells; PRV = pulse rate variability; PSI = poststroke infections; RMSSD = root mean square differences of successive RR intervals; SDNN $=$ SD of a series of RR intervals; SID = stroke-induced immunodepression.

Early infections, especially pneumonia and urinary tract infections, occur in 30\% of stroke patients and are associated with worse functional outcome, increased mortality, longer hospitalization, and increased costs for medical care. ${ }^{1}$ This increased vulnerability to infections may be at least partially explained by stroke-induced immunodepression (SID), which is characterized mainly by lymphocytopenia. ${ }^{2-5}$ The underlying mechanism of SID remains uncertain.

An early biomarker predicting poststroke infections (PSI) would aid in selecting patients for prophylactic therapy. A feasibility study found that heart rate variability (HRV) indices suggestive of a sympathovagal imbalance with parasympathetic overweight obtained within 48 hours after ischemic stroke predicted the development of subacute PSI. ${ }^{6}$ Other studies

From the Departments of Neurology (S.D.R., A.D.V., J.D.K.), Radiology (A.-M.V.B.), Hematology (M.D.W.), and Biostatistics and Medical Informatics (D.C., R.B.), Universitair Ziekenhuis Brussel, Vrije Universiteit Brussel (VUB), Brussels, Belgium; and Department of Neurology (J.D.K.), Universitair Medisch Centrum Groningen, the Netherlands.

Go to Neurology.org/nn for full disclosures. Funding information and disclosures deemed relevant by the authors, if any, are provided at the end of the article. The Article Processing Charge was paid by the authors.

This is an open access article distributed under the terms of the Creative Commons Attribution-Noncommercial No Derivative 3.0 License, which permits downloading and sharing the work provided it is properly cited. The work cannot be changed in any way or used commercially. 
Table 1 Main characteristics in patients with and without poststroke infections (PSI)

\begin{tabular}{|c|c|c|c|}
\hline & PSI $(n=24)$ & No PSI ( $n=35)$ & $p$ \\
\hline \multicolumn{4}{|l|}{ Basic characteristics } \\
\hline Age, y & $84(75-86)$ & $72(61-78)$ & 0.001 \\
\hline Female sex & $17(71)$ & $13(37)$ & 0.011 \\
\hline \multicolumn{4}{|c|}{ Basic parameters, admission } \\
\hline $\mathrm{sBP}, \mathrm{mm} \mathrm{Hg}$ & $150(140-169)$ & $152(135-167)$ & 0.793 \\
\hline $\mathrm{dBP}, \mathrm{mm} \mathrm{Hg}$ & $72(62-86)$ & $80(72-95)$ & 0.078 \\
\hline Glucose level, mg/dL & $114(97-146)$ & 113 (98-133) & 0.431 \\
\hline Temperature, ${ }^{\circ} \mathrm{C}$ & $36.7(36-37.1)$ & $36.4(36.1-36.8)$ & 0.166 \\
\hline Heart rate, beats/min & $70(62-93)$ & $73(67-86)$ & 0.975 \\
\hline \multicolumn{4}{|l|}{ Stroke characteristics } \\
\hline Stroke volume, $\mathrm{cm}^{3}$ & $20.7(5.0-92.4)$ & $2.7(1.1-8.9)$ & $<0.001^{a}$ \\
\hline Right-sided & $10(48)$ & $10(33)$ & 0.304 \\
\hline Insular involvement & $15(65)$ & 10 (37) & 0.047 \\
\hline NIHSS & $11(9-21)$ & $7(4-14)$ & 0.003 \\
\hline Thrombolysis & $20(83)$ & $20(57)$ & 0.034 \\
\hline TOAST classification & & & 0.740 \\
\hline Small vessel & 2 (8) & $6(17)$ & \\
\hline Large vessel & $2(8)$ & $4(11)$ & \\
\hline Cardioembolic & $11(46)$ & $13(37)$ & \\
\hline Undetermined & $9(38)$ & $12(34)$ & \\
\hline \multicolumn{4}{|l|}{ Stroke outcome } \\
\hline Poor outcome ${ }^{b}$ & $20(87)$ & $12(38)$ & $<0.001$ \\
\hline In-hospital mortality & $6(25)$ & 1 (3) & $0.015^{c}$ \\
\hline 3-month mortality & $8(35)$ & 1 (3) & $0.003^{c}$ \\
\hline
\end{tabular}

Abbreviations: $\mathrm{dBP}=$ diastolic blood pressure; $\mathrm{IQR}=$ interquartile range; $\mathrm{NIHSS}=\mathrm{NIH}$ Stroke Scale; sBP = systolic blood pressure.

Data are expressed as median (IQR) or $n(\%)$ as appropriate. $p$ Values calculated with Pearson $\chi^{2}$ test or Mann-Whitney $U$ test.

${ }^{\text {a }}$ No control MRI in 6 patients.

${ }^{\mathrm{b}}$ Modified Rankin scale score $>2$ at 3 months.

${ }^{c} p$ Values calculated with Fisher exact test.

suggested an association between increased sympathetic activity and PSI. ${ }^{3,7}$ We compared the number of circulating leukocyte subsets at different time points and parameters of autonomic function in ischemic stroke patients who developed infections during the first 7 days after stroke onset and those who did not.

METHODS Subjects. Sixty-six patients with acute ischemic stroke admitted within 8 hours after symptom onset or within 4 hours after wake-up symptoms were prospectively included. Ischemic stroke was diagnosed clinically, confirmed by cerebral CT on admission, and followed by brain MRI. We excluded 2 patients with a stroke mimic and 5 patients with an infection during the last week before stroke onset. Stroke severity was measured by certified neurologists using the NIH Stroke Scale on admission and on days 1 and 3. Poor functional outcome was defined as a modified Rankin Scale score of $>2$ at 3 months. Strokes were classified etiologically following the TOAST criteria. ${ }^{8}$ All patients were treated in the stroke unit according to the recommendations of the European Stroke Initiative. ${ }^{9}$

Standard protocol approvals, registrations, and patient consents. The protocol was approved by the local ethics committee. All patients or their next of kin signed a written informed consent.

Catecholamines. A 24-hour urine collection was started upon admission to the emergency department. Norepinephrine and epinephrine concentrations were measured using highperformance liquid chromatography with electrochemical detection. Detection limit was $0.05 \mu \mathrm{g} / \mathrm{L}$.

Pulse rate variability analysis. Pulse rate variability (PRV) indices were calculated from 5-minutes beat-to-beat blood pressure recordings obtained via a Nexfin monitor (BMEYE B.V., Amsterdam, the Netherlands) within the first 24 hours after stroke onset. Patients with atrial fibrillation were excluded. The Nexfin device measures noninvasive beat-to-beat arterial blood pressure by the volume clamp method through plethysmography using an inflatable finger cuff. PRV derived from noninvasive blood pressure waveforms corresponds sufficiently with traditional HRV derived from ECG in subjects at rest. ${ }^{10} \mathrm{PRV}$ was calculated using Kubios software (University of Eastern Finland, Kuopio, Finland). We calculated the most commonly used time domain and spectrum domain HRV parameters to estimate PRV on 5-minute recordings, which were $\mathrm{SD}$ of a series of RR intervals (SDNN), root mean square differences of successive RR intervals (RMSSD), high frequency range $(\mathrm{HF})$, low frequency range (LF), and LF/HF. SDNN estimates overall HRV. RMSSD evaluates short-term HRV, which reflects parasympathetic activity. HF is considered an index of parasympathetic activity, whereas LF reflects a mixture of baroreceptor-mediated parasympathetic and sympathetic activity. The LF/HF ratio is used as an index of sympathovagal balance. $^{11}$

Stroke localization and size. Brain MRI was performed between day 3 and day 5 on a 1.5-tesla MRI scanner (Philips, Eindhoven, the Netherlands) and included T1, T2, fluid-attenuated inversion recovery, and diffusion-weighted imaging (DWI) sequences. Infarction volume was calculated on the DWI sequences with dedicated software from Olea Medical (Marseille, France). The operator was blinded to the clinical data.

Poststroke infection. Infections were diagnosed during the first 7 days after stroke onset using the modified criteria of the US Centers for Disease Control and Prevention. Pneumonia was diagnosed when at least one of the former and one of the latter criteria were fulfilled: (1) abnormal respiratory examination, pulmonary infiltrates on chest $\mathrm{x}$-rays; (2) productive cough with purulent sputum, microbiological cultures from lower respiratory tract or blood cultures, leukocytosis, elevation of C-reactive protein (CRP). Diagnosis of urinary tract infection was made when at least 2 of the following criteria were present: fever $\left(>38^{\circ} \mathrm{C}\right)$, urine sample positive for nitrite, leukocyturia, and significant bacteriuria. ${ }^{12}$

Basic inflammatory parameters and leukocytes. Leukocytes and CRP were analyzed from blood drawn from an antecubital vein on admission and between 6 and 8 AM on days 1, 2, 3, 
and 7 after stroke onset. Neutrophils, monocytes, and lymphocytes were determined using flow cytometry (CELL-DYN Sapphire, Abbott Diagnostics, Abbott Park, IL). Lymphocyte subsets were enumerated with appropriate monoclonal antibodies and flow cytometry on admission and between 6 and 8 AM on days 1 and 2 after stroke onset. The following antibodies were used: $\mathrm{T}$ cells $\left(\mathrm{CD}^{+}\right)$, T-helper cells $\left(\mathrm{CD}^{+}\right)$, T cytotoxic cells $\left(\mathrm{CD}^{+}\right)$, B cells $\left(\mathrm{CD} 19^{+}\right)$, natural killer (NK) cells $\left(\mathrm{CD}{ }^{-} \mathrm{CD} 56^{+} \mathrm{CD} 16^{+}\right)$, and NK T cells (NKT) $\left(\mathrm{CD}^{+} \mathrm{CD} 56^{+} \mathrm{CD} 16^{+}\right)$. Two populations could be distinguished in the NK cells: CD16/56 dim and CD16/56 bright cells. We excluded 1 patient because of de novo diagnosis of chronic lymphatic leukemia. Reference values for the lymphocyte subsets were established on 48 healthy adults ( 24 men and 24 women) between 20 and 65 years of age. Concentrations of CRP (normal $<5 \mathrm{mg} / \mathrm{L}$ ) were measured using high-sensitivity turbidimetric immunoassay (Ortho VITROS, Ortho Clinical Diagnostics, Rochester, NY).

Statistics. We divided the patients into 2 groups: those with and those without PSI. For the CRP and leukocyte subsets, we performed a separate group-wise analysis at each time point. We performed a check for normality using the KolmogorovSmirnov test and the Q-Q plot. Continuous data are presented as median \pm interquartile range (IQR) or as mean $\pm 95 \%$ confidence interval. The Mann-Whitney $U$ test was applied to detect differences in continuous not normally distributed data. The $t$ test was used to detect differences in normally distributed data. Categorical data were compared using the $\chi^{2}$ test or the Fisher exact test where appropriate. Correlations were calculated with the Spearman rank correlation coefficient. The predictive variables (autonomic parameters, CRP, and leukocyte subsets) were not normally distributed. The data were logtransformed. Means and differences (ratio) of the means were calculated using the $t$ test and back-transformed. Data were also presented after adjustment (analysis of covariance [ANCOVA]) for age and stroke volume, 2 important potential confounders based on background knowledge and their strong association with PSI in univariate analysis. For lymphocyte subsets, we calculated each patient's percentage change between admission and day 1 and compared them using $t$ test and ANCOVA.

Sensitivity analysis was performed to determine the impact of outliers on the association between PSI and CRP and leukocyte subsets. Outliers were identified using the ROUT method $(\mathrm{Q}=1 \%)^{13}$ and the boxplot. Analysis was performed with and without outliers and the results were compared. Analyses were performed using GraphPad Prism 6.0 and SPSS 22.0 software package. A $p$ value of $<0.05$ was considered significant.

RESULTS Main characteristics. The median time window between onset of stroke and blood sampling on admission was 3 hours 2 minutes (IQR 2:284:28). In 12 patients the exact time of onset was uncertain. Twenty-four (41\%) of the ischemic stroke patients developed an infection, 9 within the first 48 hours and 15 between 48 hours and 7 days after onset. Ten patients developed pneumonia, 12 urinary tract infections, and 2 both infections.

In univariate analysis, older age, more severe stroke, larger infarction volume, insular involvement, treatment with thrombolysis, and female sex were associated with PSI (table 1). There was no correlation between age and stroke volume. PSI was associated with poor outcome, increased in-hospital mortality, and 3-month mortality (table 1).

Catecholamines. PSI was associated with increased 24hour urinary norepinephrine and epinephrine concentrations (table 2) after adjustment for glomerular filtration rate (data not shown). This association was no longer significant after adjustment for age and infarction volume (table 2).

\begin{tabular}{|c|c|c|c|c|c|c|}
\hline \multirow[t]{2}{*}{ Table 2} & in patients $\mathrm{w}$ & nd without posts & infections (PSI) & & & \\
\hline & PSI $(n=24)^{a}$ & No PSI $(n=35)^{a}$ & $\begin{array}{l}\text { Unadjusted estimated } \\
\text { ratio of means }{ }^{\mathrm{b}}\end{array}$ & $p$ & $\begin{array}{l}\text { Adjusted estimated } \\
\text { ratio of means }{ }^{c}\end{array}$ & $p$ \\
\hline \multicolumn{7}{|l|}{ Catecholamines $^{d}$} \\
\hline uNE, DO, $\mu \mathrm{g} / \mathrm{g}$ creat & $51(41-62)$ & $38(33-44)$ & $1.34(1.04-1.72)$ & 0.023 & $1.28(0.82-2.00)$ & 0.322 \\
\hline $\mathrm{uE}, \mathrm{DO}, \mu \mathrm{g} / \mathrm{g}$ creat & $10.8(8.3-14)$ & $6.8(5.3-8.8)$ & $1.58(1.09-2.28)$ & 0.016 & $1.16(0.86-1.57)$ & 0.263 \\
\hline \multicolumn{7}{|c|}{ Pulse rate variability, D1e } \\
\hline SDNN & $26(20-32)$ & $30(26-35)$ & $0.84(0.64-1.11)$ & 0.213 & $0.98(0.69-1.37)$ & 0.892 \\
\hline RMSSD & $17(15-20)$ & $23(19-28)$ & $0.74(0.58-0.94)$ & 0.013 & $0.91(0.64-1.30)$ & 0.586 \\
\hline$L F \mathrm{fft}, \mathrm{ms}^{2}$ & $95(42-216)$ & $168(100-283)$ & $0.57(0.23-1.41)$ & 0.213 & $1.06(0.36-3.07)$ & 0.918 \\
\hline LF fft, \% & $18(10-34)$ & $24(19-31)$ & $0.77(0.40-1.45)$ & 0.394 & $0.95(0.50-1.83)$ & 0.882 \\
\hline$H F \mathrm{fft}, \mathrm{ms}^{2}$ & $72(45-115)$ & $171(112-260)$ & $0.42(0.21-0.84)$ & 0.015 & $0.66(0.28-1.54)$ & 0.328 \\
\hline $\mathrm{HF} \mathrm{fft}, \%$ & $14(10-19)$ & $24(19-31)$ & $0.58(0.39-0.85)$ & 0.007 & $0.60(0.38-0.93)$ & 0.022 \\
\hline LF/HF fft & $1.3(0.6-2.8)$ & $1.0(0.7-1.4)$ & $1.33(0.66-2.70)$ & 0.411 & $1.59(0.69-3.70)$ & 0.262 \\
\hline
\end{tabular}

Abbreviations: $\mathrm{HF} \mathrm{fft}=$ high frequency range fast fourier transform; LF fft = low frequency range fast fourier transform; RMSSD $=$ root mean square differences of successive RR intervals; SDNN = SD of a series of RR intervals; $u E=$ urinary epinephrine; uNE $=$ urinary norepinephrine.

${ }^{a}$ Values are expressed as estimated means (95\% confidence interval).

b, cValues can be interpreted as the ratio of the estimated mean in the PSI group to the estimated mean in the no PSI group and were obtained by backtransforming the results from a log-transformed $t$ tes $\mathrm{t}^{\mathrm{b}}$ or analysis of covariance ${ }^{\mathrm{c}}$ (adjusted for age and stroke volume).

${ }^{\mathrm{d}} \mathrm{N}=52$.

${ }^{\mathrm{e}} \mathrm{N}=38$. 
Figure 1 Time course of C-reactive protein (CRP) and leukocyte subsets in patients with and without poststroke infections (PSI)

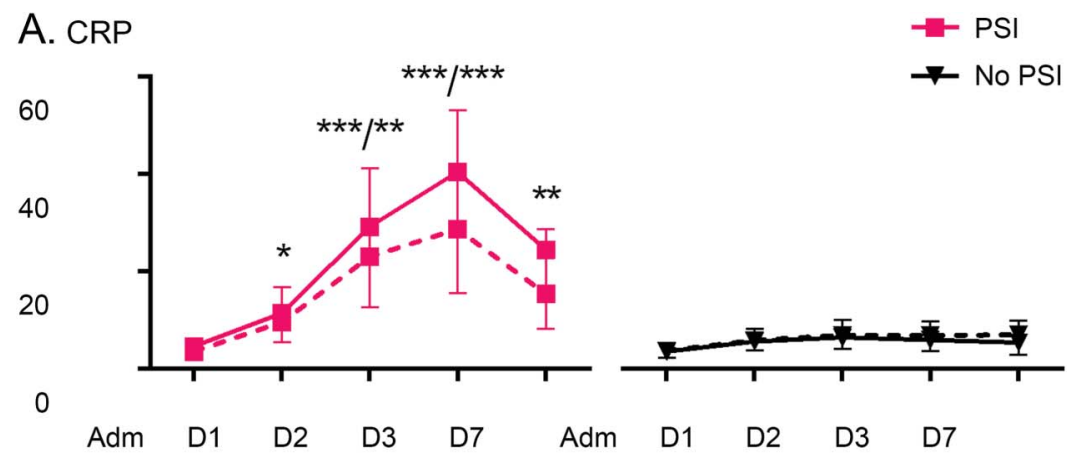

B. Neutrophils

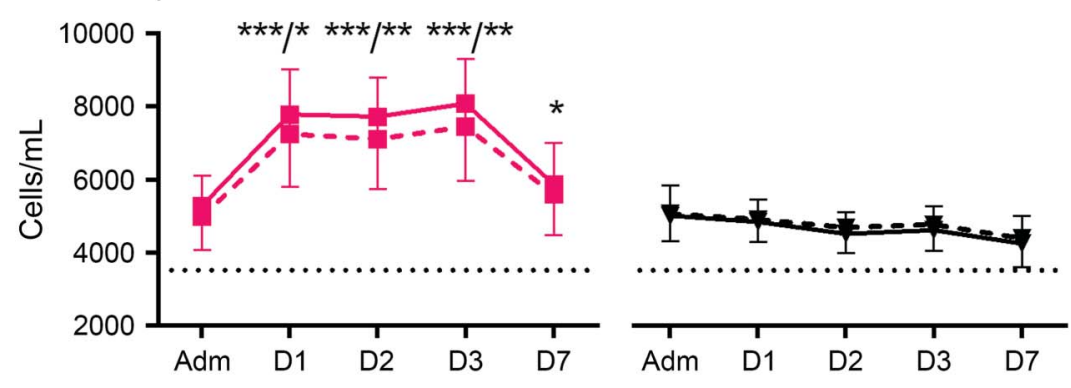

C. Lymphocytes

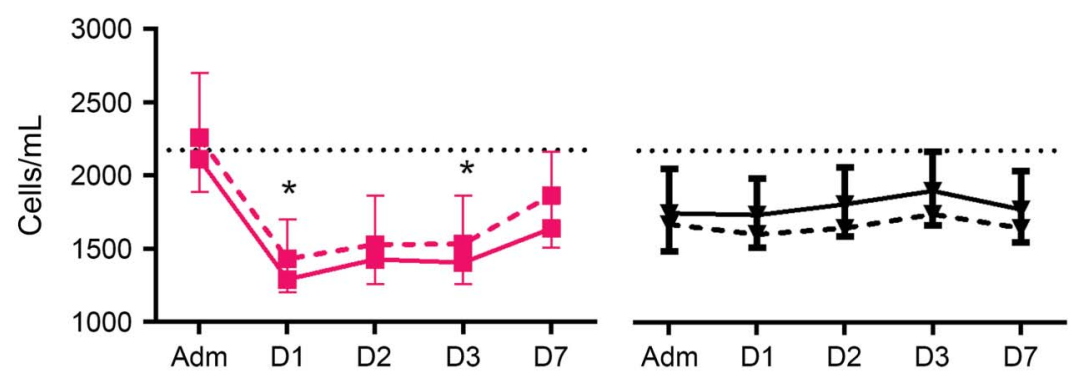

D. Monocytes

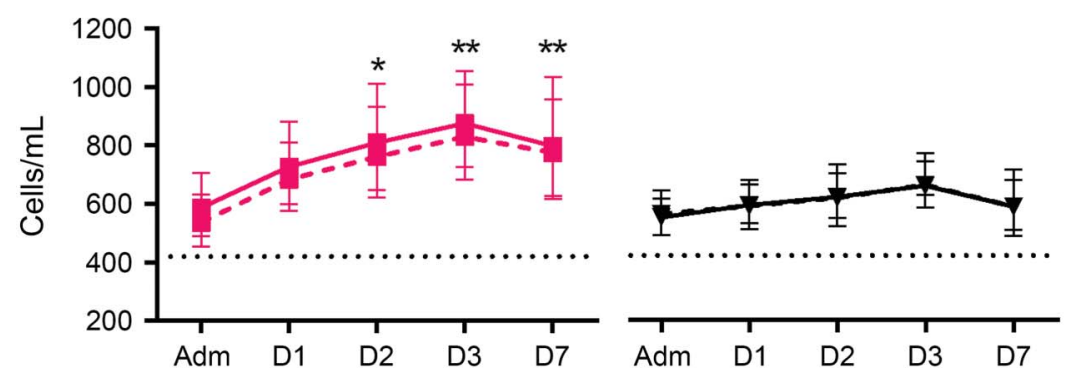

Values are expressed as means $\pm 95 \%$ confidence interval. Solid lines show the time course of unadjusted means, dashed lines show the means assuming a 74-year-old with a stroke volume of $5 \mathrm{~mL}$. The dotted line depicts the mean value in healthy individuals. ${ }^{*} p<0.05$, $* * p<0.01, * * * p<0.005$, PSI vs no PSI, unadjusted/adjusted, $t$ test (unadjusted), analysis of covariance (adjusted). $\mathrm{N}_{\mathrm{CRP}}(\mathrm{PSI})$ : admission $(\mathrm{adm})=24$, day $1=23$, day $2=16$, day $3=18$, day $7=19 ; \mathrm{N}_{\mathrm{CRP}}$ (no PSI): $\operatorname{adm}=35$, day $1=34$, day $2=26$, day $3=26$, day $7=22$; $\mathrm{N}_{\text {leukocyte subsets }}(\mathrm{PSI})$ : $\mathrm{adm}=24$, day $1=21$, day $2=20$, day $3=19$, day $7=17 ; \mathrm{N}_{\text {leukocyte }}$ subsets (no PSI): $a d m=34$, day $1=32$, day $2=29$, day $3=30$, day $7=22$.

Pulse rate variability parameters. SDNN, LF, and LF/ HF on admission were similar in patients with and without infections after stroke onset. Decreased
RMSSD and HF were associated with PSI (table 2). After adjustment for age and infarction volume, the HF (\%) remained significant $(p=0.022)$.

CRP and leukocyte subsets. PSI was associated with an increased CRP, increased neutrophil and monocyte counts, and a decreased lymphocyte count (figure 1). These associations remained after exclusion of outliers. After adjustment for age and stroke volume, increased CRP on days 2 and 3 and neutrophilic count on days 1,2 , and 3 remained significant (figure 1).

The group developing infections had an increased number of NK cells on admission $(p=0.001)$ and after adjustment for age and stroke volume $(p=$ 0.039) (figure 2). There was no correlation between NK cells on admission and either age or stroke volume in patients with and without PSI (figure 3). On day 1 , patients who developed infections had a decreased number of $\mathrm{T}$ cells $(p=0.009)$ and T-helper cells $(p=0.008)$ (figure 2 ). This finding did not remain significant after adjustment for age and stroke volume. There was no association between PSI and the number of B cells, NKT, or cytotoxic $\mathrm{T}$ cells (data not shown). PSI was associated with a decrease varying between $22 \%$ and $40 \%$ in all lymphocyte subsets from admission to day 1 after stroke onset. This decrease was not demonstrated in patients without PSI, who showed a mean increase varying between $2 \%$ and 23\% (all $p<0.005$ ). This finding remained significant after adjustment for age and stroke volume (all $p<0.05$ ) (figure 4).

Patients with increased NK cells (dichotomized over the mean) had larger infarction volumes (19.5 $\mathrm{mL}$, IQR 4.3-5.5 vs $3.14 \mathrm{~mL}$, IQR 0.8-10.9; $p=$ 0.018 ). Further analysis revealed that $98 \%$ of $\mathrm{NK}$ cells on admission and days 1 and 2 were CD16/ CD56 dim cells.

Exclusion of outliers in the lymphocyte subsets did not change the results.

DISCUSSION We report that an increase in circulating NK cells within the first hours after stroke occurred in patients who developed infections. NK cells are part of the innate immune system and mediate rapid responses to various antigens as a first-line defense against infected or transformed cells. NK cells control CNS inflammation by killing proinflammatory microglial cells, which are activated within minutes of ischemia onset. ${ }^{14-16}$ Extensive infiltration of NK cells has been described in ischemic lesions of the human brain, and it has been suggested that these cells might exert a detrimental effect on infarct volume and stroke outcome, particularly in the early poststroke phase. ${ }^{17}$ An early rise in circulating NK cells has not 
Figure 2 Time course of lymphocyte subsets in patients with and without poststroke infections (PSI)
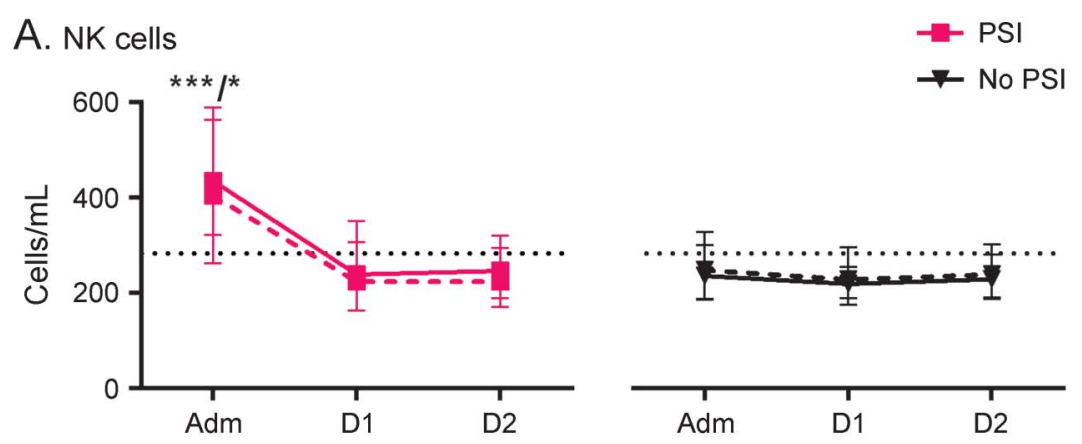

B. T cells
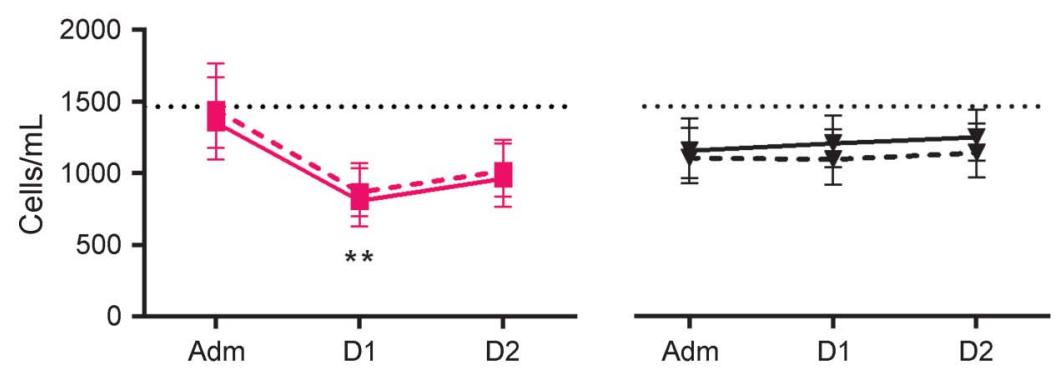

\section{T-helper cells}
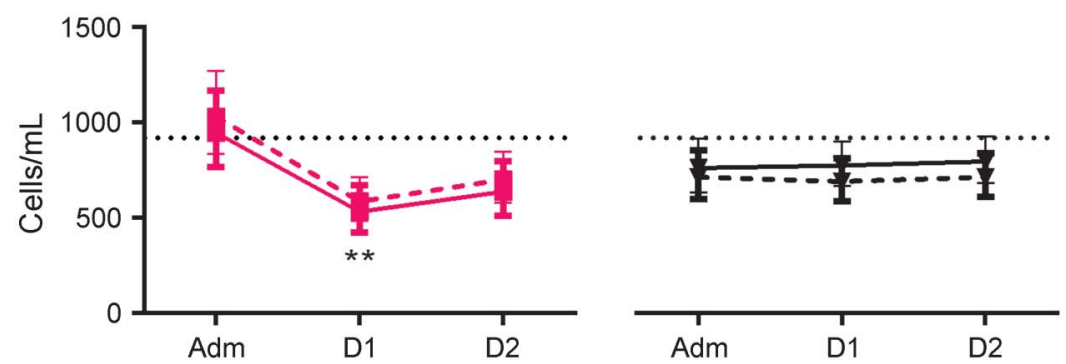

Values are expressed as means $\pm 95 \%$ confidence interval. Solid lines show the time course of unadjusted means, dashed lines show the means assuming a 74-year-old with a stroke volume of $5 \mathrm{~mL}$. The dotted line depicts the mean value in healthy individuals. $* p<0.05$, $* * p<0.01, * * * p=0.001$, PSI vs no PSI, unadjusted/adjusted, $t$ test (unadjusted), analysis of covariance (adjusted). $\mathrm{N}(\mathrm{PSI})$ : admission $(\mathrm{adm})=23$, day $1=21$, day $2=22$; $\mathrm{N}$ (no PSI): $\operatorname{adm}=31$, day $1=32$, day $2=30$. NK = natural killer.

been described before in studies investigating lymphocyte subsets in acute ischemic stroke. ${ }^{2-5}$ This may be explained by earlier inclusion in our study. Median time between stroke onset and blood sampling was 3 hours. One of the previous studies also performed early blood sampling with a median time window of 3 hours and showed a trend to increased NK cells in patients who developed an infection. ${ }^{4}$

The transient increase in NK cells in patients with PSI was followed by a drop in all circulating lymphocyte subsets. This supports previous studies showing an association between PSI and reduced lymphocytes, ${ }^{2,4,5}$ especially $\mathrm{T}$ cells $s^{3-5}$ and T-helper cells. $^{2-5}$
In stroke patients developing infections, we found decreased RMSSD and HF component in PRV and increased 24-hour urinary levels of both norepinephrine and epinephrine. After age and volume adjustment, only decreased HF power remained significant. This might be suggestive of a sympathovagal imbalance with sympathetic overweight preceding the infections. This supports earlier studies that showed elevated plasma metanephrine and normetanephrine levels ${ }^{7,18}$ and increased urinary norepinephrine levels in association with PSI. ${ }^{3,19}$ However, Günther et al. found that increased HF power, reduced LF power, and decreased LF/HF ratio, suggestive of parasympathetic overactivity, predicted subacute infection in acute ischemic stroke. ${ }^{6}$ Urinary catecholamines do not directly reflect end-organ sympathetic activity in the spleen or lymph nodi, which are important organs in the mobilization of leukocytes. However, urinary concentrations of epinephrine and norepinephrine correlate with circulating concentrations in the blood, which are a measure of sympathoadrenal medullary activity, ${ }^{20}$ reflecting global sympathetic activity.

Similar to the hyperacute phase of stroke, acute mental and cold stress has been associated with a rapid increase in lymphocytes, especially NK cells, followed by a decrease in lymphocytes if stress persists. $^{21,22}$ The increase in circulating lymphocytes and particularly in NK cells reflects a mobilization of lymphocytes into the blood from the marginal blood pool. Norepinephrine and epinephrine released during stress reduce NK cell adhesion to the vascular endothelium via $\beta$-adrenergic receptors on their surface, resulting in an increase in the number of NK cells in peripheral blood. ${ }^{23}$ Activation of the sympathetic nervous system increases blood pressure and vascular shear forces, which may also promote the release of marginated cells into the bloodstream. ${ }^{24}$ The $\beta$-adrenergic antagonists nadolol and propranolol could prevent the increase in NK cells in rats with acute social stress. ${ }^{24}$ The subsequent immune depression probably reflects a complex process including cell redistribution and catecholamine-mediated increased cell death. Lymphocytes migrate to the ischemic brain lesion ${ }^{17}$ and to sites of origin such as bone marrow and spleen. ${ }^{25,26}$ Chronic $\alpha$-adrenergic stimulation increased lymphocyte apoptosis in the spleen and lymph nodes and decreased circulating B and T cells in rats. ${ }^{27}$ Administration of the $\beta$-adrenergic blocker propranolol prevented the decrease in all peripheral blood lymphocyte subsets in a mouse model of focal cerebral ischemia. ${ }^{7}$

Our results should be interpreted with caution because of the small number of patients and the possible influence of untested confounding factors. Therefore, larger studies are required to investigate whether a high NK cell count within the first hours 
Figure 3 Relation between natural killer cells on admission and age (A) and stroke volume (B) in patients with and without poststroke infections (PSI)

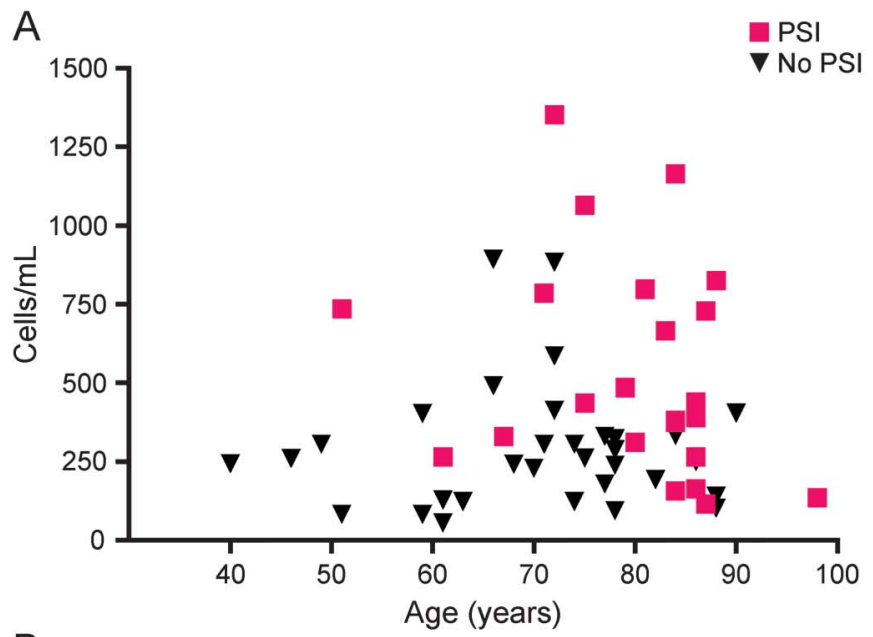

B

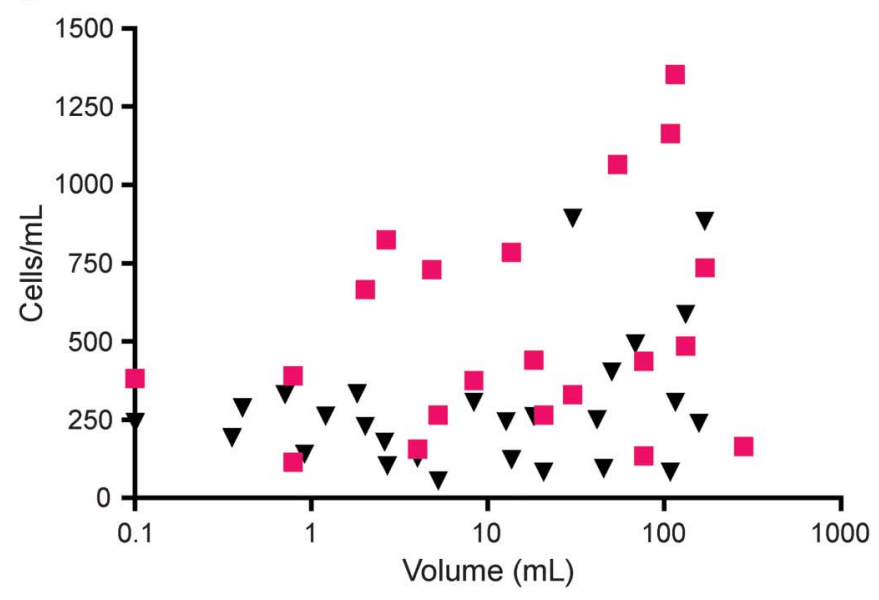

Figure 4 Percentage of change in lymphocyte subsets between admission and day 1 in patients with and without poststroke infections (PSI)

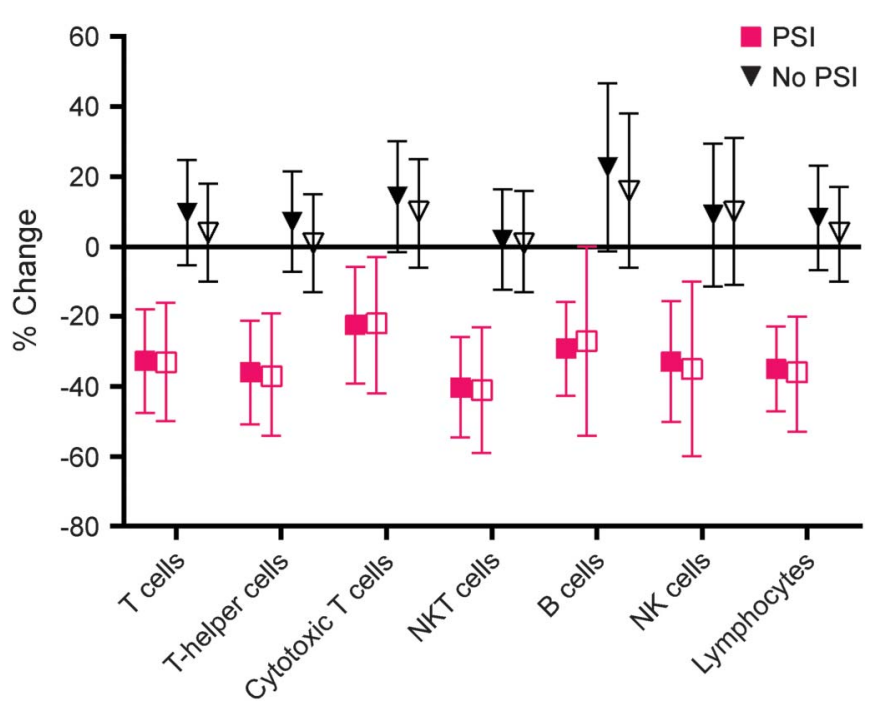

Values are expressed as means $\pm 95 \%$ confidence interval. Filled symbols show the unadjusted means, open symbols show the means assuming a 74-year-old with a stroke volume of $5 \mathrm{~mL}$. All $p$ (unadjusted) $<0.005$, PSI vs no PSI, $t$ test. All $p$ (adjusted) $<0.05$, PSI vs no PSI, analysis of covariance. $\mathrm{N}(\mathrm{PSI})=21, \mathrm{~N}($ no PSI) $=31$. NK = natural killer. after ischemic stroke might serve as a biomarker for identifying patients at risk for infections and to further elaborate on the interplay between the autonomic nervous system and lymphocyte subsets in acute ischemic stroke.

\section{AUTHOR CONTRIBUTIONS}

Sylvie De Raedt: drafting and revising the manuscript for content, including medical writing for content; study concept or design; analysis or interpretation of data; acquisition of data; statistical analysis; study supervision or coordination; obtaining funding. Aurelie De Vos: drafting/revising the manuscript for content, including medical writing for content; analysis or interpretation of data; acquisition of data. Anne-Marie Van Binst: drafting/revising the manuscript for content, including medical writing for content; analysis or interpretation of data. Marc De Waele: drafting/revising the manuscript for content, including medical writing for content; analysis or interpretation of data. Danny Coomans: statistical analysis. Ronald Buyl: statistical analysis. Jacques De Keyser: drafting/revising the manuscript for content, including medical writing for content; study concept or design; analysis or interpretation of data; statistical analysis; study supervision or coordination; obtaining funding.

\section{STUDY FUNDING}

This work was funded by an unrestricted grant from Astra Zeneca.

\section{DISCLOSURE}

S. De Raedt has received research support from Astra Zeneca. A. De Vos, A.-M. Van Binst, M. De Waele, D. Coomans, and R. Buyl report no disclosures. J. De Keyser has received research support from Astra Zeneca. Go to Neurology.org/nn for full disclosures.

Received June 5, 2014. Accepted in final form December 30, 2014.

\section{REFERENCES}

1. Westendorp WF, Nederkoorn PJ, Vermeij JD, Dijkgraaf MG, van de Beek D. Post-stroke infection: a systematic review and meta-analysis. BMC Neurol 2011;11:110.

2. Vogelgesang A, Grunwald U, Langner S, et al. Analysis of lymphocyte subsets in patients with stroke and their influence on infection after stroke. Stroke 2008;39:237-241.

3. Klehmet J, Harms H, Richter M, et al. Stroke-induced immunodepression and post-stroke infections: lessons from the preventive antibacterial therapy in stroke trial. Neuroscience 2009;158:1184-1193.

4. Urra X, Cervera A, Villamor N, Planas AM, Chamorro A. Harms and benefits of lymphocyte subpopulations in patients with acute stroke. Neuroscience 2009;158:1174-1183.

5. Haeusler KG, Schmidt WU, Fohring F, et al. Cellular immunodepression preceding infectious complications after acute ischemic stroke in humans. Cerebrovasc Dis 2008;25:50-58.

6. Günther A, Salzmann I, Nowack S, et al. Heart rate variability—a potential early marker of sub-acute post-stroke infections. Acta Neurol Scand 2012;126:189-196.

7. Chamorro A, Amaro S, Vargas M, et al. Catecholamines, infection, and death in acute ischemic stroke. J Neurol Sci 2007;252:29-35.

8. Adams HP Jr, Bendixen BH, Kappelle LJ, et al. Classification of subtype of acute ischemic stroke. Definitions for use in a multicenter clinical trial. TOAST. Trial of Org 10172 in Acute Stroke Treatment. Stroke 1993;24:35-41.

9. Toni D, Chamorro A, Kaste M, Lees K, Wahlgren NG, Hacke W; EUSI Executive Committee, EUSI Writing Committee. Acute treatment of ischaemic stroke. European Stroke Initiative. Cerebrovasc Dis 2004;17(suppl 2):30-46. 
10. Schäfer A, Vagedes J. How accurate is pulse rate variability as an estimate of heart rate variability? A review on studies comparing photoplethysmographic technology with an electrocardiogram. Int J Cardiol 2013;166:15-29.

11. Zygmunt A, Stanczyk J. Methods of evaluation of autonomic nervous system function. Arch Med Sci 2010;6:11-18.

12. Harms H, Prass K, Meisel C, et al. Preventive antibacterial therapy in acute ischemic stroke: a randomized controlled trial. PLoS One 2008;3:e2158.

13. Motulsky HJ, Brown RE. Detecting outliers when fitting data with nonlinear regression - a new method based on robust nonlinear regression and the false discovery rate. BMC Bioinformatics 2006;7:123.

14. Lunemann A, Lunemann JD, Roberts S, et al. Human NK cells kill resting but not activated microglia via NKG2Dand NKp46-mediated recognition. J Immunol 2008;181: 6170-6177.

15. Hao J, Campagnolo D, Liu R, et al. Interleukin-2/interleukin2 antibody therapy induces target organ natural killer cells that inhibit central nervous system inflammation. Ann Neurol 2011;69:721-734.

16. Hao J, Liu R, Piao W, et al. Central nervous system (CNS)-resident natural killer cells suppress Th17 responses and CNS autoimmune pathology. J Exp Med 2010;207: 1907-1921.

17. Gan Y, Liu Q, Wu W, et al. Ischemic neurons recruit natural killer cells that accelerate brain infarction. Proc Natl Acad Sci USA 2014;111:2704-2709.

18. Urra X, Cervera A, Obach V, Climent N, Planas AM, Chamorro A. Monocytes are major players in the prognosis and risk of infection after acute stroke. Stroke 2009; 40: 1262-1268.

19. Harms H, Reimnitz P, Bohner G, et al. Influence of stroke localization on autonomic activation, immunodepression, and post-stroke infection. Cerebrovasc Dis 2011;32: 552-560.

20. Moleman P, Tulen JH, Blankestijn PJ, Man in 't Veld AJ, Boomsma F. Urinary excretion of catecholamines and their metabolites in relation to circulating catecholamines. Six-hour infusion of epinephrine and norepinephrine in healthy volunteers. Arch Gen Psychiatry 1992;49: 568-572.

21. Kimura K, Isowa T, Ohira H, Murashima S. Temporal variation of acute stress responses in sympathetic nervous and immune systems. Biol Psychol 2005;70:131-139.

22. Willemsen G, Carroll D, Ring C, Drayson M. Cellular and mucosal immune reactions to mental and cold stress: associations with gender and cardiovascular reactivity. Psychophysiology 2002;39:222-228.

23. Benschop RJ, Nijkamp FP, Ballieux RE, Heijnen CJ. The effects of beta-adrenoceptor stimulation on adhesion of human natural killer cells to cultured endothelium. Br J Pharmacol 1994;113:1311-1316.

24. Engler H, Dawils L, Hoves S, et al. Effects of social stress on blood leukocyte distribution: the role of alpha- and beta-adrenergic mechanisms. J Neuroimmunol 2004; 156:153-162.

25. Stefanski V, Peschel A, Reber S. Social stress affects migration of blood $\mathrm{T}$ cells into lymphoid organs. J Neuroimmunol 2003;138:17-24.

26. Engler H, Bailey MT, Engler A, Sheridan JF. Effects of repeated social stress on leukocyte distribution in bone marrow, peripheral blood and spleen. J Neuroimmunol 2004;148:106-115.

27. Stevenson JR, Westermann J, Liebmann PM, et al. Prolonged alpha-adrenergic stimulation causes changes in leukocyte distribution and lymphocyte apoptosis in the rat. J Neuroimmunol 2001;120:50-57. 


\title{
Neurology \\ Neuroimmunology \& Neuroinflammation
}

\author{
High natural killer cell number might identify stroke patients at risk of developing \\ infections \\ Sylvie De Raedt, Aurelie De Vos, Anne-Marie Van Binst, et al. \\ Neurol Neuroimmunol Neuroinflamm 2015;2; \\ DOI 10.1212/NXI.0000000000000071
}

This information is current as of February 12, 2015

\section{Updated Information \& \\ Services \\ References \\ Citations \\ Subspecialty Collections}

Permissions \& Licensing

Reprints including high resolution figures, can be found at:

http://nn.neurology.org/content/2/2/e71.full.html

This article cites 27 articles, 6 of which you can access for free at: http://nn.neurology.org/content/2/2/e71.full.html\#\#ref-list-1

This article has been cited by 2 HighWire-hosted articles: http://nn.neurology.org/content/2/2/e71.full.html\#\#otherarticles

This article, along with others on similar topics, appears in the following collection(s):

All Immunology

http://nn.neurology.org//cgi/collection/all_immunology

All Infections

http://nn.neurology.org//cgi/collection/all_infections

Autonomic diseases

http://nn.neurology.org//cgi/collection/autonomic_diseases

Information about reproducing this article in parts (figures,tables) or in its entirety can be found online at:

http://nn.neurology.org/misc/about.xhtml\#permissions

Information about ordering reprints can be found online:

http://nn.neurology.org/misc/addir.xhtml\#reprintsus

Neurol Neuroimmunol Neuroinflamm is an official journal of the American Academy of Neurology.

Published since April 2014, it is an open-access, online-only, continuous publication journal. Copyright $\odot$ 2015 American Academy of Neurology. All rights reserved. Online ISSN: 2332-7812.

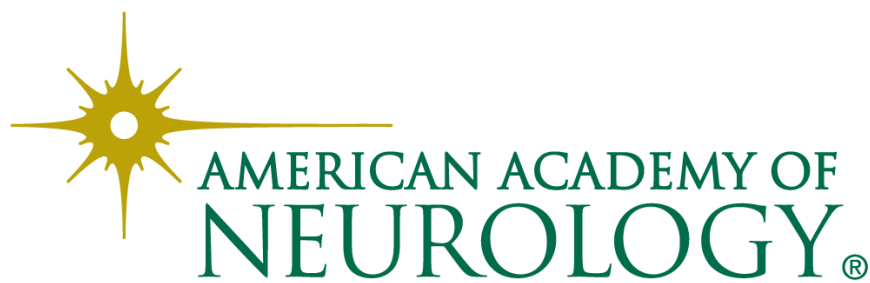

